\title{
Erratum to: ABJS Carl T. Brighton Workshop on Health Informatics in Orthopaedic Surgery
}

\section{Editorial Comment}

\section{Christian J. H. Veillette MD, MSc, FRCSC}

Published online: 14 August 2010

(C) The Association of Bone and Joint Surgeons( 2010

\section{Erratum to: Clin Orthop Relat Res \\ DOI 10.1007/s11999-010-1455-9}

The URL for the NHS was incorrectly listed as http://www. informatics.nhs.uh. The correct web address is http://www. connectingforhealth.nhs.uk/.

The online version of the original article can be found under doi:10.1007/s11999-010-1455-9.

(Veillette CJH. ABJS Carl T. Brighton Workshop on Health Informatics in Orthopaedic Surgery: Editorial Comment. Clin Orthop Relat Res. 20107 July. [Epub ahead of print])

C. J. H. Veillette ( $\square)$

Division of Orthopaedic Surgery, University of Toronto, Toronto

Western Hospital, 399 Bathurst Street, Toronto, ON M5T 2S8,

Canada

e-mail: christian.veillette@uhn.on.ca; orthonet@gmail.com 